\title{
Narmada Valley irrigation plan a test case for World Bank
}

\section{New Delhi}

Opposition to a giant irrigation plan for the Narmada river basin is gaining momentum in India. A group of some 200 leading scientists, ecologists and administrators has presented a petition urging Prime Minister Rajiv Gandhi to scrap the Narmada Valley Project, financed by the World Bank, and to look for environmentally safer alternatives.

Signatories to the petition include Dr M. S. Swaminathan, president of the International Union for Conservation of Nature and an adviser to the World Bank. By making him their ally, Indian environmentalists hope to project the Narmada Valley Project as a test case for the World Bank's new policy of considering the environment along with economics.

The Narmada river basin covers the states of Madhya Pradesh, Maharashtra and Gujarat. The plan is to construct 30 major, 135 medium and 3,000 minor dams on the river and its tributaries.

Three major dams have already been built and about $\$ 300$ million has so far been spent on a fourth, the Sardar Sarovar dam in Gujarat. Work on the fifth dam, Narmada Sagar in Madhya Pradesh, has just begun. The project will mean eviction of an estimated one million people, including 67,000 'tribals', and submergence of 300,000 hectares of forest, containing several archaeological sites. The government's own Department of Forests has admitted that the social cost of the Narmada Valley Project will be about $\$ 3$ million.

The blueprint for the project was prepared more than 15 years ago when protection of the environment was a low priority. Swaminathan and other campaigners now believe that earlier calculations were wrong and that the water supply from the Narmada had been seriously overestimated.

They also doubt the wisdom of largescale canal irrigation in water-retentive black soil. Irrigation from the first two dams in the scheme has caused soils to become waterlogged and crop yields to fall. A study conducted by the Indian Institute of Science for the Narmada Sagar project shows that 40 per cent of the command area will become waterlogged.

The Department of Forests has indirectly admitted that although plants totalling $2,500 \mathrm{MW}$ capacity will be installed, there will be firm power generation of only 523.5 MW.

Despite opposition, the central and state governments are going ahead with the project. The Department of Forests has granted clearance for the project without waiting for the environmental risk assessment studies the department itself had initiated. Meanwhile the World Bank has withdrawn its support for the scheme until agreement is reached on a plan to resettle the people who will be displaced by the dams.

\section{US legislators attack greenhouse gases}

\section{Washington}

A comprehensive bill aimed at slowing the build-up of greenhouse gases in the atmosphere was introduced into both houses of the US Congress last week. The 200-page bill, the work of Claudine Schneider (Republican, Rhode Island) and George Brown (Democrat, California), resurrects much of the enthusiasm for energy efficiency of the oil-shock era but with a new imperative - failure to act quickly could mean global catastrophe.

Drought, forest fires, heat waves and hurricanes in the United States this summer and disastrous floods in Bangladesh are all cited by Congresswoman Schneider as omens of the bigger disasters to come if the rise in greenhouse gases and attendant global warming remains unchecked.

Schneider believes that by focusing on more efficient use of energy, the remedies detailed in the Global Warming Prevention Act can be provided for nothing. Better energy use will mean increased US industrial productivity and provide "costfree' the desired fall in output of carbon dioxide, the principal greenhouse gas.

Overall, Schneider sees the bill providing energy savings of $\$ 5,000$ million per decade. Among specific measures are tax rebates to encourage consumers to buy
India's river valley projects are notorious for cost over-runs, and total cost may reach $\$ 70,000$ million - to irrigate two million hectares of land. "This works out to an investment of $\$ 28,000$ per hectare", claimed a leading article in an Indian newspaper, "making it by far the world's most expensive way of watering the land". Indian ecologists say that modern technology must be able to offer a cheaper solution.

K. S. Jayaraman

energy-efficient cars, new standards for vehicle fuel performance and a tax penalty for inefficient 'gas guzzling' vehicles. Taken together, these will ensure that average automobile fuel consumption will reach 45 miles per gallon by 1999 .

Alongside fuel efficiency measures are incentives designed to spur development of renewable energy resources, to prevent deforestation and to increase reafforestation internationally. The bill even contains measures to promote universal family planning services, recognizing that population growth ultimately drives increased energy use and thus carbon dioxide output.

Schneider launched the bill in the Congress's final weeks to ensure that there is a 'blueprint for action' when Congress reconvenes and a new president takes office in January.

But although the bill enjoys support from both Democrats and Republicans, there is no guarantee that it will ever become law. In the past week, automobile interests won a reduction in fuel efficiency targets to make it easier for them to market large cars, and attempts to restart congressional debate of the Clean Air Act, which would have hit at the worst polluters, were abandoned.

Alun Anderson

\section{Swapping power for trees in the Americas}

\section{Washington}

Pressure groups in the United States have been quick to make fear of a global warming an ally to their various causes. Legislators espousing increased energy efficiency were first off the mark, but not far behind are proponents of nuclear power who sense that much may be made of its unique advantage - it creates energy without generating carbon dioxide. Natural-gas companies have also been beating the drum; gas-fired power stations produce just half as much carbon dioxide as those fired by coal.

One company about to open a new coalfired power station has announced the imaginative operation of planting enough trees to fix more carbon than the plant will produce. But at a rough estimate, the whole continental United States west of the
Missouri would have to be reafforested to start reducing global carbon dioxide levels.

AES Thames, a subsidiary of Applied Energy Services, will at least be sure that its 180-MW plant being built at Uncasville, Connecticut, will make no net contribution to the level of greenhouse gases. The plant's production of 15 million tons of carbon over the next $\mathbf{4 0}$ years will be offset by the planting of 52 million trees in Guatemala.

In Guatemala the project is to be managed by the aid agency CARE, which will work with the Guatemalan forest service and the Peace Corps. The project was put together by the World Resources Institute which sees it as an inexpensive way to combat the problems of deforestation in developing countries while helping prevent global warming. Alun Anderson 